Research Institute near Sandringham under Mr. G. O. Searle. There are also stands illustrating, for New Zealand, the cultivation and uses of phormium fibre, and for India, jute, sunn hemp, coir and palmyra. The Hard Fibres Section of the British Empire Producers' Organisation has arranged a comprehensive group of exhibits of sisal and sisal manufactures, the collection and display of which were entrusted to Dr. Gibson and his sisal research staff at Lambeg. Other stands display Mauritius hemp, Ceylon coir, West African piassava, Cyprus hemp and manila hemp from Borneo.

\section{British Speleological Research}

It will be remembered that one of the purposes with which the British Speleological Association, of which Sir Arthur Keith is president, was founded recently, was that of holding annual conferences for the discussion of problems relating to this branch of investigation and for the co-ordination of the results of research in all matters affecting the study of caves. The first of such conferences will be held, by invitation of the Mayor and Corporation, at Buxton on July 24-27 next. The conference is free to members of the Association, but others who are interested in cave exploration may attend on payment of a fee of five shillings. The Association is already actively at work in various directions. A bibliography of papers on British speleology is in course of preparation, and a catalogue is being compiled of all prehistoric artefacts now in public or private collections which have been found in British caves. Preparations are also being made for an important undertaking, which will be of considerable scientific interest and ultimately of no little public service. A survey is to be made of the more important underground rivers and streams with the view of assisting the Inland Water Survey Committee of the Ministry of Health. In view of the necessity of conservation of water supply and the weaknesses in this important branch of public service revealed recently by climatic conditions, this work of the Association cannot fail to assume a position of some importance. Particulars of the forthcoming conference and of the objects of the Association may be obtained from the Honorary Secretary and Treasurer, Mr. G. H. Hill, The Museum, Buxton.

\section{Announcements}

THe first soirée this year of the Royal Society will be held in the rooms of the Society at Burlington House, London, W.1, on May 28. The second soirée will be held on June 30, and, in connexion with the Second International Congress for Microbiology, a further soirée will be held on July 29 .

AT the annual general meeting of the Ray Society held on March 12, the following officers were reelected : President, Sir Sidney Harmer; Treasurer, Sir David Prain; Secretary, Dr. W. T. Calman. Dr. Robert Gurney was elected a vice-president, and Dr. G. P. Bidder, Dr. Malcolm Smith, and Captain Cyril Diver were elected new members of Council. It was announced that the first volume of Mr. F. J. Killing- ton's monograph of the British Neuroptera, forming the issue for 1935, would shortly be published. The second volume of this work will form the issue for 1936. Among the works in preparation are monographs of the British freshwater planarians, by $\mathrm{Mr}$. P. Ullyott, and on the British Tunicata, by Dr. John Berrill.

A Discussion on "The Design of a Family Budget", with special reference to food, will be held at a joint meeting at the Royal Society of Arts of the Engineers' Study Group on Economics and the Association of Scientific Workers on March 31 at 7.45 p.m. A report from Section A of the Engineers' Study Group will be presented by Dr. E. H. Tripp, and the discussion will be opened by Sir John Orr; contributions to the discussion will be made by Sir Daniel Hall, Sir Frederick Gowland Hopkins, Mr. G. D. H. Cole and others. Further particulars can be obtained from the honorary secretary of the Engineers' Study Group, Hazlitt House, Southampton Buildings, Chancery Lane, W.C.2 (telephone, Holborn 1068).

IN connexion with the exhibition of Very Low Temperatures at present on view in the Science Museum, a series of lectures will be delivered in the Lecture Theatre of the Museum on Wednesdays from April 1 until May 27. Each lecture will commence at 5.15 p.m. Prof. M. W. Travers will speak on the development and uses of low temperature; in. dustrial uses of low temperatures will be discussed in three lectures by C. G. Bainbridge, J. T. Randall and Dr. I. J. Faulkner, respectively; while the approach to the absolute zero will form the subject of lectures by Dr. J. D. Cockcroft, Prof. F. A. Lindemann and Prof. F. Simon, respectively. Admission, which is free, will be by ticket only, for which applications should be sent as soon as possible to the Director, The Science Museum, London, S.W.7.

Applications are invited for the following appointments, on or before the dates mentioned:

A head of the Engineering Department of the County Technical College, Wednesbury - The Director of Education, County Education Offices, Stafford (April 4).

A principal of the Radcliffe Junior Technical School and Technical College-The Secretary of Education, Town Hall, Radcliffe (April 4).

A lecturer in mathematies and physics in the Chelten. ham Technical College-The Secretary (April 6).

An assistant (grade III) for abstracting scientific and technical literature for the Department of Scientific and Industrial Research-The Establishment Officer, 16 Old Queen Street, Westminster, S.W.1 (April 15).

A University professor of anatomy in St. Bartholo. mew's Hospital Medical College--The Academy Registrar, University of London, S.W.7 (April 17).

A senior lecturer in biochemistry in the University of Liverpool-The Johnston Professor of Biochemistry (April 17).

A lecturer in agricultural chemistry in the Edin. burgh and East of Scotland College of AgricultureThe Secretary (April 18). 